\title{
THE GONADS, LARVAE, AND BUDDING OF THE POLYSTYELID ASCIDIANS STOLONICA AND DISTOMUS
}

\author{
By N. J. Berrill \\ From the Plymouth Laboratory and McGill University, Montreal
}

(Text-figs. I-6)

Stolonica socialis (Hartmeyer) and Distomus variolosus Gaertner are two species of styelid ascidians with a capacity for budding and colony formation, found on both sides of the western end of the English Channel. Distomus occurs immediately below the level of extreme low spring tides, commonly encrusting the sides of rocks and laminarian bases. Stolonica is more usually found by dredging in deeper water, on the upper sides of stones or gravel bottom. Their external appearance and general internal anatomy have been well described and beautifully illustrated in the monograph of LacazeDuthiers and Delage (1892), while the process of budding has been investigated by Selys-Longchamps (I9I7).

In spite of their local abundance and striking appearance, little attention has been given them by English biologists and much of general interest has been overlooked, while an over-emphasis of the importance of the pattern systems of botryllid colonies has masked the close relationship of all the budding styelid-like ascidians. This relationship is discussed further, after descriptions have been given of the breeding cycles of Stolonica and Distomus.

\section{STOLONICA SOCIALIS (HARTMEYER)}

Mature colonies (Fig. I A) consist of loosely associated individuals from Io to $15 \mathrm{~mm}$. high, of a bright yellow-orange when alive, each with independent branchial and atrial siphons.

With regard to the internal anatomy (Fig. I B) the main points of interest are that the branchial sac has three true moderately well-developed branchial folds on each side. The heart has one end opening, as in many other ascidians, at the posterior end of the endostyle. A considerable part of the tubular heart extends anteriorly and mid-ventrally, immediately below the endostyle.The neural gland is dorsal to the ganglion. The most striking feature, however, is the distribution and nature of the gonads.

\section{Gonads}

The gonads (Fig. I B-D) are arranged in three rows, one along each side of the endostyle, and one on the left following the outer course of the intestine. They are essentially hermaphrodite organs imbedded in the atrial or mantle 
wall. Each testis and ovary has its own duct extending as part of the atrial lining, opening into the atrial cavity.

The fully formed gonad consists of a testis divided into from six to a dozen lobes all emptying into a common sperm duct which projects into the atrial
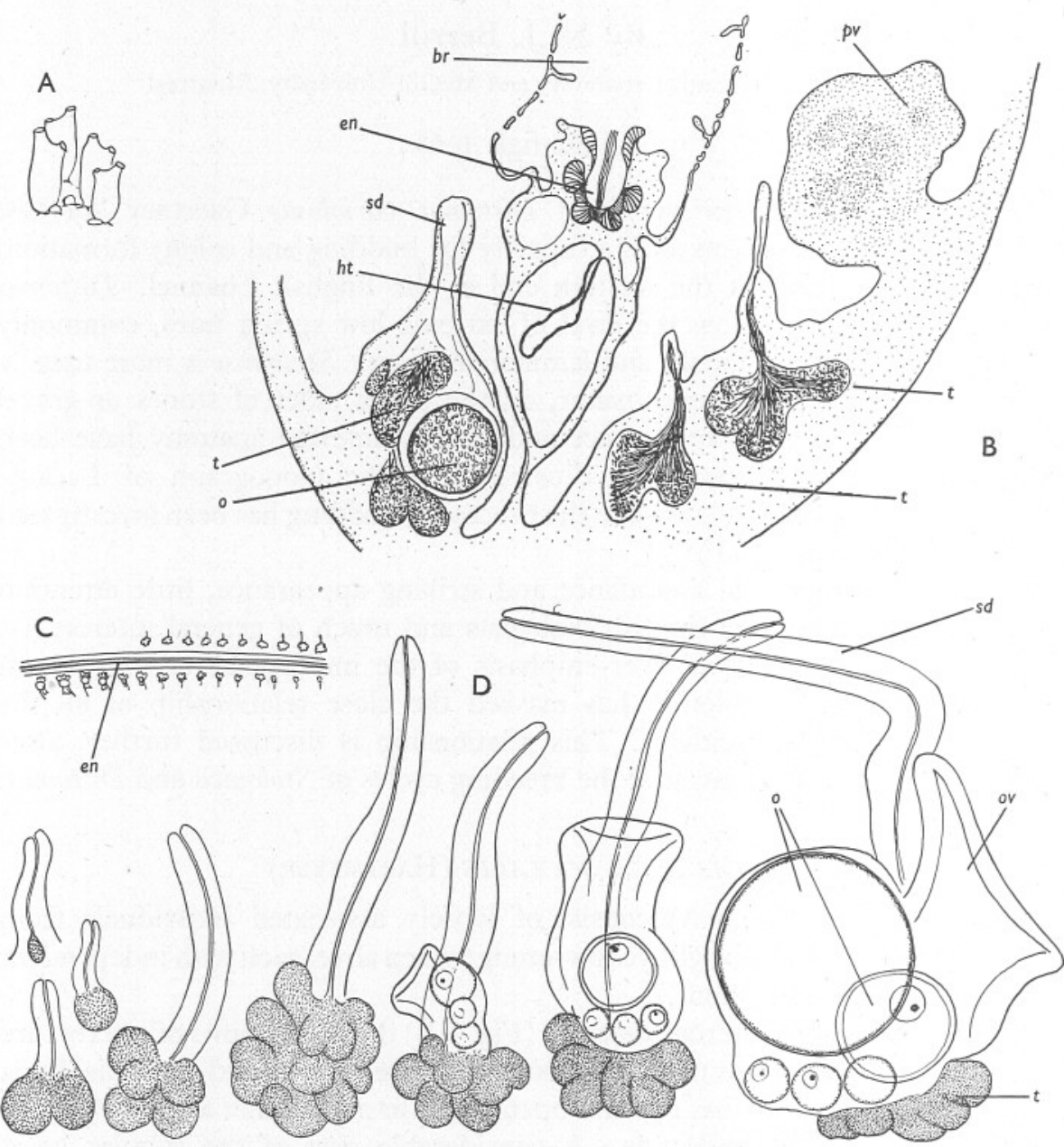

Fig. I. Stolonica socialis. A, zooids. B, cross-section of mature zooid to show position of heart ventral to the endostyle, and gonads in the mantle wall on each side of the mid-ventral line. C, endostyle with male gonad series on one side and male to hermaphrodite series on the other. D, graded samples of hermaphrodite series. $b r$, branchial sac; $e n$, endostyle; $h t$, heart; $o$, ripe egg; ov, oviduct; $p v$, parietal vesicle or endocarp; sd, sperm duct; $t$, testis.

cavity within a long slender extension of the inner atrial wall, and an ovary with a single large ovum and several small oocytes, with a very short and very wide oviduct opening to the atrial cavity. 
The gonads, however, are not all alike. The series along the right side of the endostyle and the series following the course of the intestine on the left side each consists of testes only, essentially the same as the male component of the hermaphrodite unit just described; while the series along the left side of the endostyle is a graded one, and at its posterior end from four to six units are hermaphrodite, each with a fully grown ovum (Fig. I C). At the anterior end only male components are present, those at the extreme anterior end being relatively extremely small. Intermediate units occur along the middle range of the series.

As the male gonads become progressively smaller it is evident that the number of the testis follicles is correspondingly reduced, the size of the individual follicle remaining unaffected until the number is reduced to one, and only further diminution results in a reduced follicle size. Also the length of the sperm tube is directly proportionate to the number of follicles or mass of testis tissue.

The size of the male gonad increases until a maximum is reached approximately midway along the side, after which it remains virtually the same size, although there is some indication of further but slight increase. The female gonad first appears about halfway along the series as a group of small partly grown ova associated with a relatively small oviduct. The size of the unit increases progressively, passing towards the posterior end, until a maximum size is reached about one-quarter the length of the series from its end. The maximum units have a fully grown ovum, one partly grown, and several oocytes showing no sign of growth at all. The smaller units may have a partly grown ovum and undeveloped oocytes, but no fully grown ovum.

The series, which is illustrated in Fig. I D, may accordingly be regarded as a single series of increasing unit sizes, progressive size increases giving rise to progressively larger male gonads until a maximum is attained, further size increases resulting in first rudimentary and finally large functional female gonads.

The male series on the right of the endostyle and alongside the intestine exhibits less of a size gradient and its members do not attain the tissue mass of the hermaphrodites. It is believed that unless the initial rudiment of a gonad exceeds a certain critical size, it will not grow to a size capable of forming or segregating oocytes, and unless oocytes are formed no oviduct will develop.

The majority of the middle zone hermaphrodites probably do not mature as female gonads, since, shortly after the maximum gonads have shed their eggs and the tadpoles developed, the parent zooid becomes senescent and is sloughed off. As far as can be determined the maximum gonads at the posterior end of the series each yield two ripe eggs in the course of the breeding season, three at the most and one at a time. The submaximal gonads produce but one ripe egg coinciding with the shedding of the last egg of the larger units, while the smaller units near the beginning of the hermaphrodite series fail to produce any. Whether, given sufficient time, they could do so is not known, for their time is cut short by the death of the whole organism. 


\section{Development of the Egg}

Development of the egg as far as the formation of the active tadpole larva takes place within the atrial cavity. The mature eggs are the largest, though not the yolkiest, known among ascidians, with a diameter of approximately $0.70 \mathrm{~mm}$. They are equalled in size only by those of Ecteinascidia turbinatum Herdman.

Cleavage is unmodified, with the same sequence of pattern established for Styela by Conklin (1905). Gastrulation occurs between the sixth and seventh cleavage as in all other ascidians and is typically embolic. In spite of the large size of the egg and its rather heavy yolk content, the yolk is distributed as in smaller and less yolky eggs and has no apparent affect upon either cleavage or gastrulation, other than a general retardation of developmental rate (Fig. 2 A).

At $16^{\circ} \mathrm{C}$. the tadpole hatches by digestion of the egg membrane about 5 days after fertilization, although at that time it is still inactive. It continues. development for another 4 days within the atrial cavity of the parent before it attains functional differentiation and is liberated. During this last period there is considerable growth of the trunk, while the changes in the tail are mainly those of fine differentiation of the locomotory tissues. The freeswimming period usually lasts about 2 days, but may be shorter or considerably longer. It may be greatly affected by the length of time the fully formed tadpole has been retained within the parental atrial chamber. The heart commences beating about 4 days after the tadpole first becomes attached, the four rows of gill slits function 2 days later, and the gut functions fully after another 5 days. It is this last state (Fig. 2 B) that should be regarded as the end of egg development, and not the attainment of the active tadpole stage.

\section{Tadpole Larva}

The tadpole (Fig. 2 B) is about the largest and most effective swimmer among ascidian larvae. The trunk is approximately $\mathrm{I} \mathrm{mm}$. and the tail, exclusive of the cuticular fin, $2 \mathrm{~mm}$. long. At a temperature of $\mathrm{I} 6-\mathrm{I} 7^{\circ} \mathrm{C}$. the tadpole has a free-swimming period of from 24 to $48 \mathrm{hr}$. for the great majority. Swimming is somewhat intermittent under laboratory conditions, depending greatly upon external stimulation. At this temperature the stroke of the tail is about 8-I2 per sec., and progress about $25-30 \mathrm{~mm}$. per sec. Tadpoles show response both to light and gravity, being positively heliotropic and negatively geotropic during the first few hours at least.

During the active phase the trunk remains ovoid and streamlined. The tail fin, a cuticular secretion, is vertical, retaining the primitive position in spite of the large size of the egg, and as the result of the developing tail being coiled horizontally around the trunk rather than vertically. Both branchial and atrial invaginations are formed at this time, the atrial being median and single from 

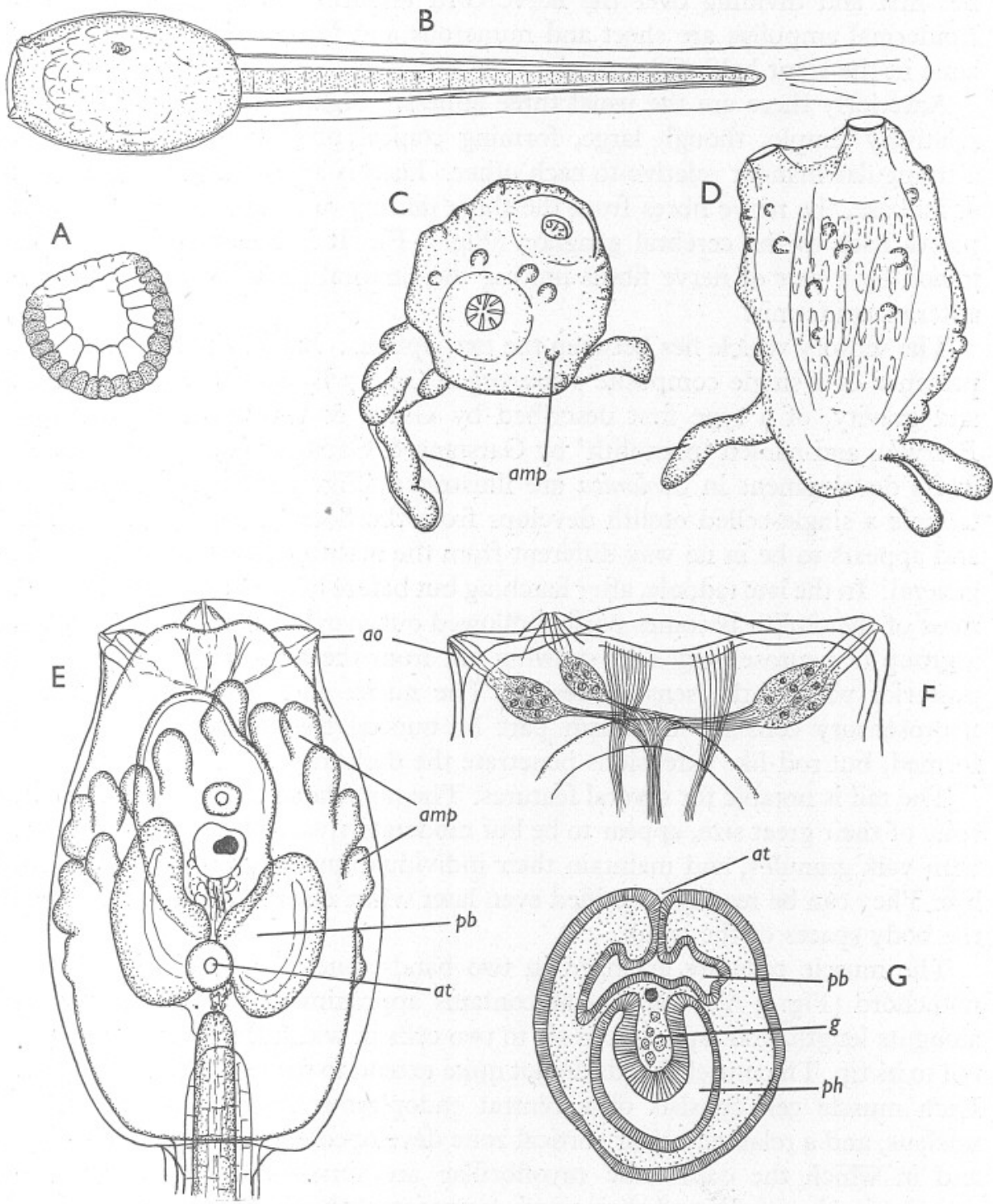

Fig. 2. Development and tadpole structure of Stolonica. A, gastrula. B, active tadpole. C, metamorphosed individual with siphons open. D, fully developed oozooid with four rows of gill slits. E, trunk of tadpole from dorsal side showing adhesive organs, ampullae, sensory vesicle and peribranchial sacs. F, anterior region of tadpole showing nerves and ganglia to adhesive organs and anterior epidermis. G, cross-section of tadpole through atrial invagination to show ectodermal origin of peribranchial sacs. amp, ampulla; $a o$, adhesive organ; at, atrial siphon; $g$, ganglion; $p b$, peribranchial sac; $p h$, pharynx. 
the first and dividing over the nerve cord to form the peribranchial sacs. Epidermal ampullae are short and numerous and form an irregular circular zone in the front half of the trunk.

Anteriorly there are the usual three adhesive organs (Fig. 2 E). They are relatively simple, though large, forming conical projections distributed in a triangular manner relative to each other. Each is supplied with a ganglion at its base, the nerve fibres from the three uniting to form a single fibre that passes back to the cerebral ganglion (Fig. 2 F). It is accompanied but not joined by a pair of nerve fibres uniting the cerebral ganglion with the midanterior epidermis.

The sensory vesicle lies between the two siphons. It is characterized by the presence of a single composite sense-organ (Fig. $3 \mathrm{E}$ ) sensitive to both light and gravity, of a type first described by Grave \& Woodbridge (1924) for Botryllus and named 'photolith' by Garstang \& Garstang (1928). Two stages in its development in Stolonica are illustrated (Fig. 3, C-F). In the early tadpole a single-celled otolith develops from the floor of the sensory vesicle and appears to be in no way different from the otolith of ascidian tadpoles in general. In the late tadpole, after hatching but before liberation, the pigmented mass of the otolith becomes partly hollowed out, partly extended, to embrace a group of neurosensory cells growing out from the sensory ganglion at the posterior wall of the sensory vesicle. The nuclei and cell bodies of these neurosensory cells for the main part lie outside the pigmented cup thus formed, but rod-like extensions penetrate the dark mass.

The tail is notable for several features. The notochord cells, about forty, in spite of their great size, appear to be but moderately vacuolated, are congested with yolk granules, and maintain their individual integrity throughout larval life. They can be readily identified even later when resorbed and separated in the body spaces of the trunk.

The muscle cells are arranged in two bands, one along each side of the notochord (Fig. 3 A). Each band contains approximately twenty-four cells along its length, and tapers from six to two cells in width from the base of the tail to its tip. The muscle bands do not quite extend to the tip of the notochord. Each muscle cell consists of a central endoplasmic region containing the nucleus, and a relatively clear cortical zone developed equally well on all sides and in which the contractile myofibrillae are formed. Even after metamorphosis, these cells and their zones are recognizable in the resorbed tissue. The most striking feature is the continuity of the myofibrillae from cell to cell (Fig. 3 B). The myofibrils pass as continuous structures, following a slightly spiral course, from the broad base to the narrow tip of the muscle band as a whole, and there is no doubt that the band functions as a unit. The fibrils pass from cell to cell in the cortical or ectoplasmic zone, and there is a definite superficial syncitial or symplasmic state of the tissue. A similar condition has been described by Caswell Grave (I92I) for Amaroucium, and by Conklin 
(I93I) for Styela. Stolonica tadpoles are exceptionally favourable for demonstrating this condition, owing to the large size of the muscle cells and relatively enormous thickness of their hyaline zone.
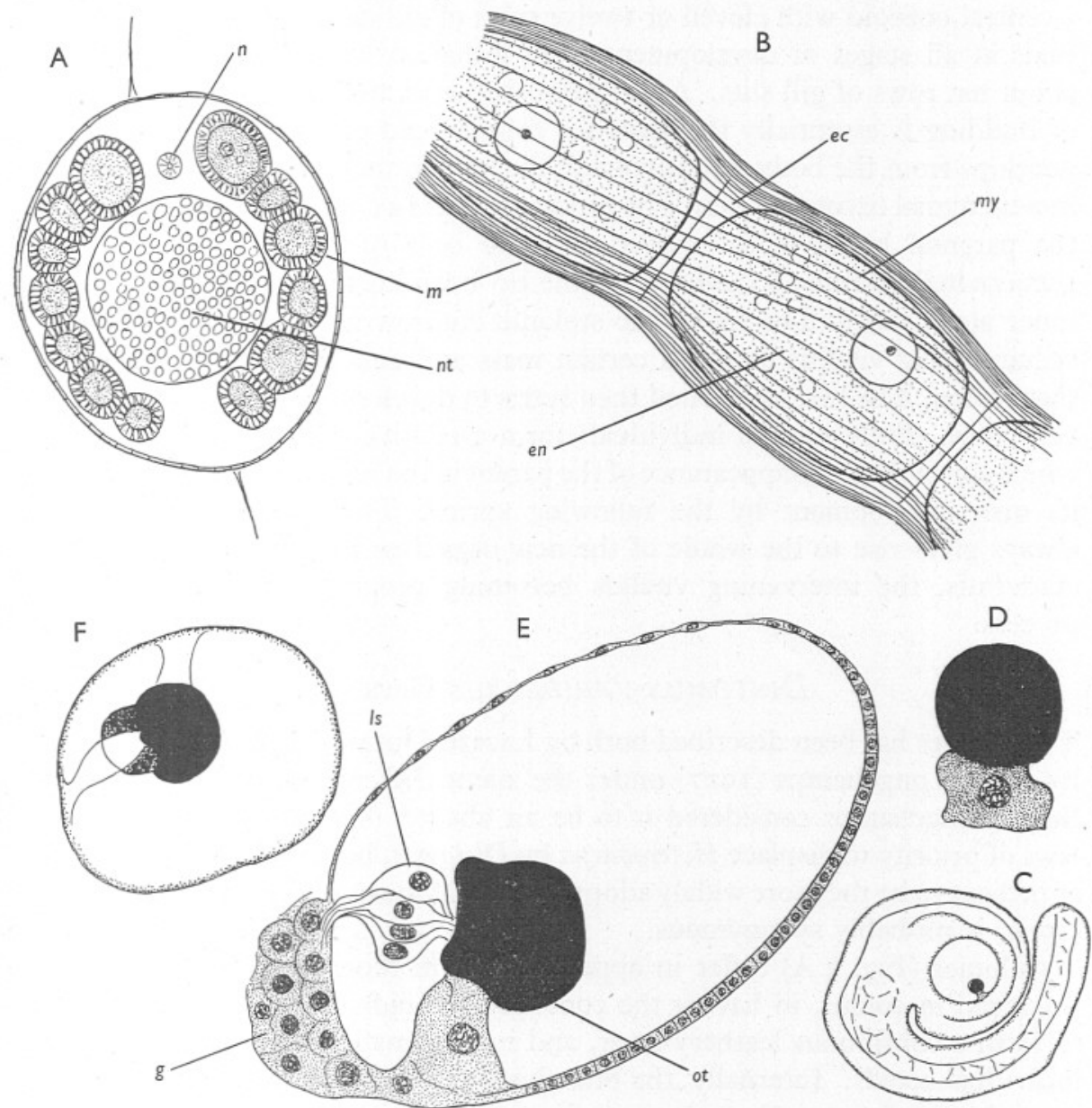

Fig. 3. Tail and sensory vesicle of Stolonica tadpole. A, cross-section of tail showing organization of muscle cells. B, adjacent muscle cells showing thick ectoplasmic zone and continuity of myofibrillae from cell to cell. C, embryonic tadpole with newly formed otolith. $\mathrm{D}$, otolith of $\mathrm{C}$ at same magnification as figure $\mathrm{E}$. E, sensory vesicle with otolith invaded by light-sensitive neurons to form 'photolith'. F, dorsal view of vesicle showing extension of otolith pigment. ec, ectoplasm; en, endoplasm; $g$, ganglion; $l s$, light-sensitive cells; $m$, muscle cell; $m y$, myofibril; $n$, neural tube; $n t$, notochord; ot, otolith.

\section{Budding}

The process of budding has been described at length by Selys-Longchamps (1917), to which little can be added. There is no sign of budding in the oozooid when it first functions with the primary four rows of gill slits (Fig. 2 D, G), 
nor for several weeks after, during which growth occurred, though not enough to increase the number of rows of gill slits. Selys-Longchamps, however, figures (I9I7, plate III) a young colony from dredged material consisting of a central oozooid with eleven or twelve rows of gill slits, and with about eight buds at all stages of development from initiation to functional zooids with about ten rows of gill slits. Apart from size it seems evident that the process of budding is essentially the same for colonies old or young. An outgrowth develops from the body wall involving the epidermis, the atrial lining, and the mesenchymal tissue between. The process extends a considerable distance from the parental body, while reserve nutritive cells of the circulating system, pseudovitelline cells, accumulate at the tip between the outer epidermal and inner atrial tubes. The tip of the stolonic outgrowth constricts off after the accumulating vitellus attains a certain mass and cuts off circulation through that region. The bud so isolated then starts to develop, although the process is very slow. Fully mature individuals form a relatively large bud of this type which survives the disappearance of the parent in the late summer and completes its own development by the following spring. The internal atrial vesicle always gives rise to the whole of the new organism with the exception of its epidermis, the intervening vitellus becoming progressively utilized in the process.

\section{Distomus VARIOLOSUS GaERTNER}

This species has been described both by Lacaze-Duthiers \& Delage (1892) and by Selys-Longchamps (I9I7) under the name Heterocarpa glomerata Alder. Selys-Longchamps considered it to be an absurd obedience to intransigent laws of priority to displace Heterocarpa by Distomus, but this last name appears at present to be the more widely adopted. The Allaeocarpa apolis of Michaelsen (I904) is probably synonymous.

Colonies (Fig. $4 \mathrm{~A}$ ) differ in appearance from those of Stolonica in being brick red in colour, in having the constituent zooids closely packed together to form a continuous leathery layer, and in the smaller maximum size of the individual zooids. Internally, the branchial sac is without true folds, although on each side there are three groups of internal longitudinal bars, undoubtedly the remnants of what were originally three branchial folds (Fig. 4 B). The neural gland is dorsal to the ganglion, while the heart extends anteriorly beneath the endostyle as in Stolonica, and as in Stolonica the gonads are unique, though in their own way.

\section{Gonads}

The zooids, as in almost all ascidians, are functional hermaphrodites, but are peculiar in possessing only testes on the right side and ovaries on the left.

The testes (Fig. 4 C, G) are comparatively simple, the smallest being more or less pear-shaped, larger ones becoming relatively elongated, a maximum 

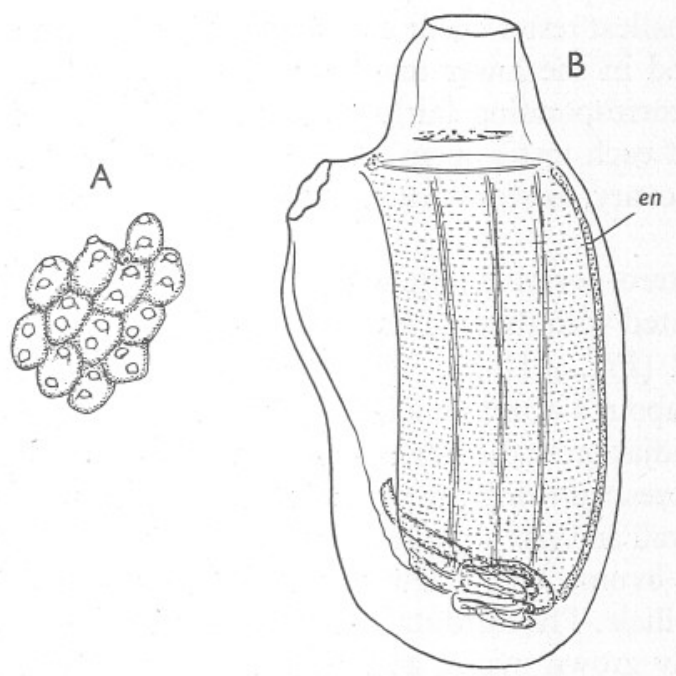

C

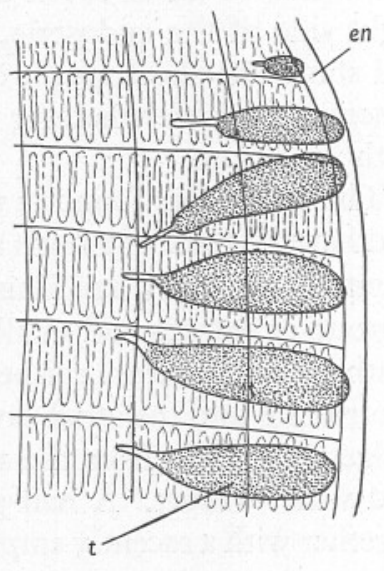

D
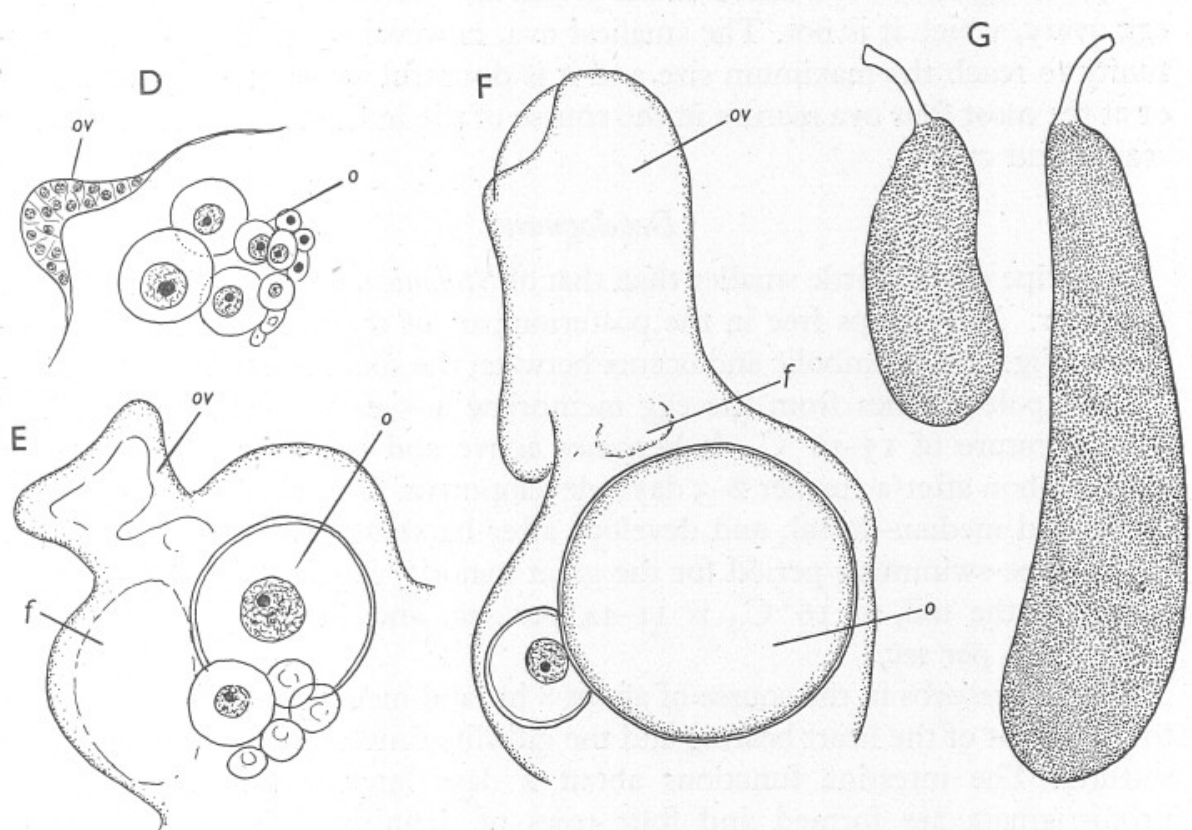

Fig. 4. Distomus variolosus. A, zooids. B, zooid enlarged. C, part of ventral branchial sac showing relative position and number of testes. D, young stage in development of ovary and oviduct. E, ovary with one egg discharged, and numerous oocytes. F, typical mature ovary with ripe egg. G, minimum and maximum sized testes. en, endostyle; $f$, empty follicle; $o$, ova; ov, oviduct; $t$, testis. 
width seemingly apparent. The smallest testes occur anteriorly, Usually there is a series of six or seven arranged in the lower mantle wall parallel to the right side of the endostyle, one corresponding fairly closely to each row of gill slits. The short sperm duct of each testis opens towards the dorsal side. There is no trace whatever of an ovary, however rudimentary, in association with the testes.

The ovaries are found in the antero-dorsal mantle wall of the opposite side, and have no trace of a testis associated with them. Three stages in the development of an ovary are illustrated (Fig. $4 \mathrm{D}-\mathrm{F}$ ). The youngest consists of a group of oocytes and small ova, about a dozen in all, lying beneath the atrial epithelium. The atrial epithelium adjacent to the ovary shows a local thickening protruding into the atrial cavity, foreshadowing the oviduct. The second stage bulges as a whole from the atrial wall and has a moderately large though short and wide oviduct. A half-grown ovum, with a few small ova, are present, together with a recently emptied follicle. The third stage has the fully developed oviduct, a mature ovum, a slightly grown ovum, and an old empty follicle. Only one egg ripens at a time and the gonad has been considered to be a single egg ovary, which it is not. The smallest ova, however, do not have an opportunity to reach the maximum size and it is doubtful whether more than three or at the most four ova mature in the course of the individual zooid's breeding season and cycle.

\section{Development}

The ripe egg is a little smaller than that of Stolonica, approximately $0.6 \mathrm{~mm}$. diameter. It develops free in the posterior part of the atrial cavity. Gastrulation (Fig. $5 \mathrm{~A}$ ) is embolic and occurs between the sixth and seventh cleavage. The tadpole hatches from the egg membrane $4-5$ days after fertilization at a temperature of $15-16^{\circ} \mathrm{C}$. It becomes active and is liberated through the atrial siphon after a further $2-3$ days' development. The atrial invagination is single and median-dorsal, and develops after hatching and before liberation.

The free-swimming period for the great majority is from I8 to $30 \mathrm{hr}$. The stroke of the tail, at $16^{\circ} \mathrm{C}$., is II-I4 per sec. and the tadpole progresses 20-25 mm. per sec.

The tail resorbs in the course of about $8 \mathrm{hr}$. and metamorphosis is complete to the extent of the heart beating and the gill slits functioning IO-I2 days after settling. The intestine functions about 2 days later. As in Stolonica no protostigmata are formed and four rows of definitive stigmata appear as independent perforations from the beginning (Fig. 5 C).

The tadpole (Fig. 5 B) is large, though not so large as that of Stolonica, and is brick red. The cuticular fin of the tail is vertical, the developing tail being coiled horizontally around the embryo, so that it does not become twisted through ninety degrees as it would if the tail retained the primitive vertical position in the limited perivitelline space. A pair of flukes extend postero- 
laterally from the trunk. They may conceivably have some stabilizing function in swimming. In the anterior half of the trunk a ring of sixteen epidermal ampullae, rarely more, encircle it. The ring is very regular compared with the same feature in tadpoles of Stolonica. Three adhesive organs, arranged triangularly, are formed at the anterior tip. During metamorphosis the tail resorbs, the tail cuticle is thrown off, and the trunk shortens along its main axis. At the same time the ring of ampullae extend individually, secreting test substance and making fast to the substratum, taking over the function of the transient adhesive organs.

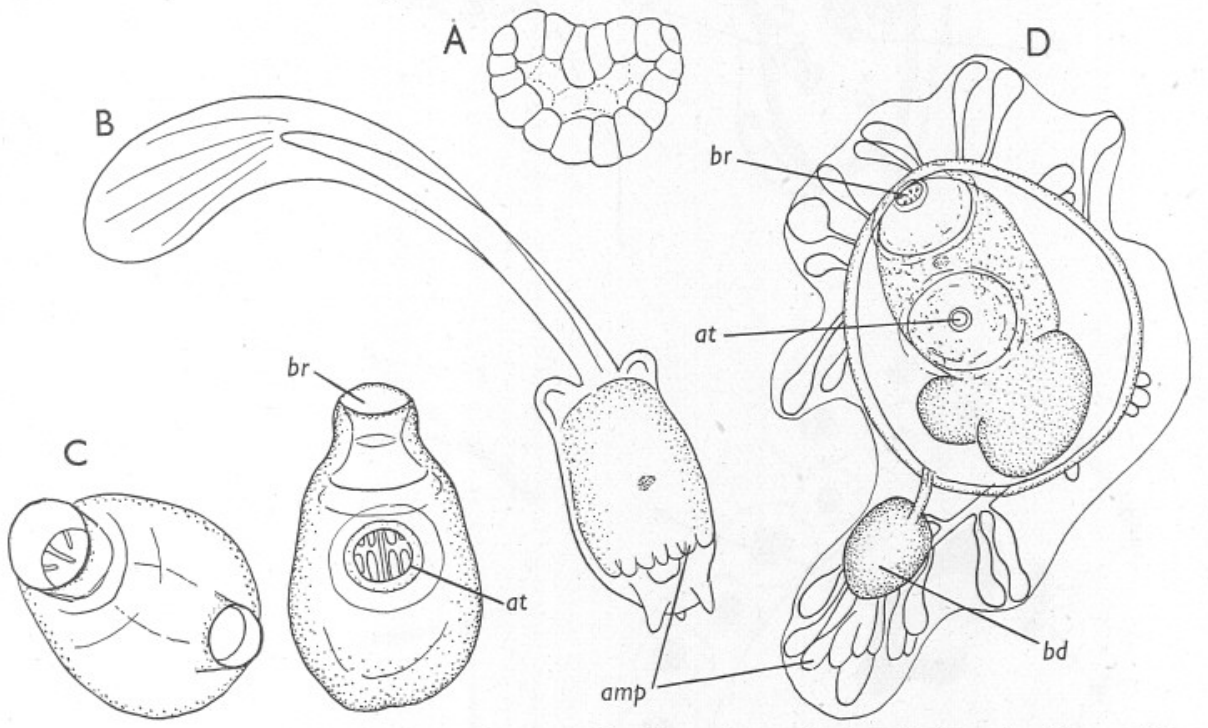

Fig. 5. Development of Distomus. A, gastrula. B, active tadpole. C, functional oozooids. $\mathrm{D}$, oozooid after several weeks' growth with first bud and numerous ampullae. amp, ampulla; $a t$, atrial siphon; $a o$, adhesive organ; $b d$, bud; $b r$, branchial siphon.

The adhesive organs are large but simple, consisting of conical epidermal projections containing a hollow core of glandular cells that secrete the adhesive substance. Each has a nerve ganglion associated with its base and a nerve fibre connecting with the central neural ganglion (Fig. $6 \mathrm{E}$ ). The fibres remain separate from each other until they reach the sensory vesicle region. Two lateral nerve fibres pass from the central ganglion to a pair of lateral larval ganglia.

The sensory vesicle contains a single sense organ, a typical 'photolith' as in Stolonica and Botryllus (Fig. 6D). As in these forms, it develops early as a unicellular otolith from the floor of the sensory vesicle, and late in the course of tadpole development a group of neuro-sensory cells project from the postero-dorsal wall of the vesicle and enter the hollowed-out and extended mass of otolith pigment. The tadpoles are responsive both to light stimuli and gravity. 

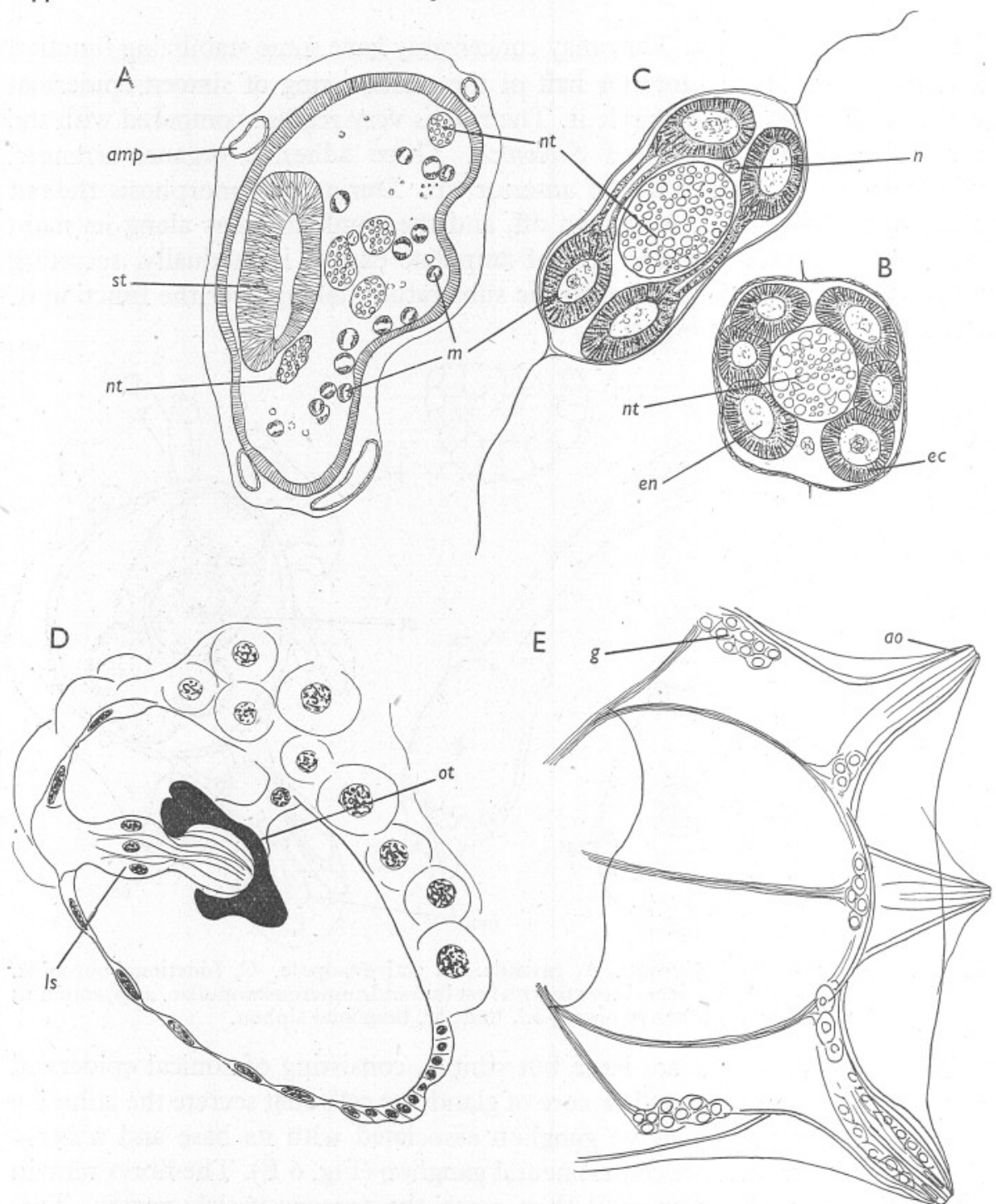

Fig. 6. Distomus. A, section through metamorphosed tadpole to show muscle cells and yolky notochord cells scattered through body cavity. B, C, sections of tail through middle and posterior part to show nature and arrangement of muscle cells. D, sensory vesicle with typical photolith. E, anterior region of tadpole showing nerves and ganglia associated with the adhesive organs and anterior ectoderm. amp, ampulla; ao, adhesive organ; $e c$, ectoplasm; $e n$, endoplasm; $g$, ganglion; $l s$, light sensitive cells in photolith; $m$, muscle cell; $n$, neural tube; $n t$, notochord; ot, otolith; st, stomach.

The notochord consists of approximately forty yolk-laden cells arranged in single series. The muscle cells (Fig. $6 \mathrm{~B}, \mathrm{C}$ ) are arranged in two bands, one on each side of the notochord, each band consisting of three cells in crosssection at the base of the tail, two near the tip. The notochord extends 
posteriorly slightly beyond the muscle bands. Myofibrillae are continuous from cell to cell throughout the length of the band, taking the same somewhat spiral course as in Stolonica. They are confined to the relatively enormously thick hyaline zone. After resorption of the tail, notochord cells still richly laden with yolk granules and muscle cells now isolated and with the fibrilla zone obvious are clearly recognizable scattered through the primary body cavity (Fig. $6 \mathrm{~A}$ ).

\section{Budding}

Buds are produced in essentially the same manner as in Stolonica. Local regions of the posterior and ventral body wall, involving epidermis, mesenchyme, and atrial lining, grow out to form the bud stolon. Usually the outgrowth is extremely short and the bud develops at its tip in close conjunction with the parent and without severing its connexion. Winter buds, however, are produced similar to those of Stolonica, with large accumulations of pseudovitelline cells between the epidermis and the inner atrial tube. These masses survive the dissolution of the parents after the sexual breeding season and themselves develop to functional maturity by the following spring.

The first buds appear relatively early, from the wall of the oozooid, a few weeks after the settling of the tadpole, at the time the most anterior of the primary four rows of definitive stigmata is dividing into two rows (Fig. $5 \mathrm{D}$ ).

Selys-Longchamps (1917, plate III) shows two partly fused young colonies each with an oozooid with about a dozen rows of stigmata, giving rise to five or six buds at various stages. There is evidently a considerable accumulation of reserve cells between the epidermal and atrial layers even in the buds of these early colonies and this appears to be the main source of bud nutrition rather than the communicating stalk with the parent zooid. The epidermis contributes only epidermis, and all other tissues and organs are derived from the atrial epithelium forming the internal vesicle.

\section{The Polystyelid AND Botryllid Ascidians}

The most recent systematic treatise on ascidians is the monograph by Van Name (1945) on North and South American forms. In this account the Botryllidae are assigned full family status, but are described as belonging to the same stock as the Styelidae, and as quite closely related to some of the compound members of that family. Van Name is not in favour of separating the compound from the simple Styelidae as a separate family (Polyzoidae, syn. Polystyelinae), as Ärnbäck-Christie-Linde (1923) and others have suggested. Any discussion of such forms as Stolonica and Distomus therefore involves the botryllids on the one hand and the non-budding styelids on the other.

Van Name's setting apart of the Botryllidae in their old accepted status is based on the presence of zooid systems and common cloacal apertures, and 
on differences he believes to exist with regard to gonads and budding. His refusal to separate polystyelids from simple styelids is based on the close relationship of Polyandrocarpa, a polystyelid, and Polycarpa (a simple styelid), when only adult features of the mature isolated individual are contemplated. If only adult characters are considered, there is little doubt that the two forms merit merely a generic distinction.

It is evident that much of the diversity of opinion is due to varying interpretation of similarities in adult and reproductive features. If the classification is to reflect actual relationships, it is important to decide whether similarity of adult structure is basic and other characters convergent, or whether budding and larval characters can be used to unify a group. It is considered here that the last is possible and there is a natural group of styelid ascidians set apart from other styelids by two unique characters, a type of budding and a larval sense-organ not to be found elsewhere among tunicates.

Botryllids and polystyelids are the only members of the order Pleurogona ( $=$ Stolidobranchia $=$ Ptychobranchia $)$ that bud. Since no member of this order possesses a posterior abdominal or post-abdominal extension of the body, and the epicardium survives only in one family and as a highly specialized renal organ, there is no possibility of the strobilating epidermal-epicardial budding processes of the Enterogona (=Phlebobranchia + Aplousobranchia), nor is there any structure comparable to the budding stolon of the Perophoridae. The styelid-botryllid type of budding is always fundamentally an outgrowth or outgrowths of the whole body wall at the level of the pharynx, consisting of a hollow protrusion of both epidermal and atrial epithelia with mesenchymatous tissue enclosed between them. It is usually called 'palleal' budding, and the atrial epithelium is invariably the primary morphogenetic tissue. Nothing comparable to this type of budding occurs among any other forms. It accordingly remains to be shown that the marked variability of budding among the botryllids and polystyelids is that of one basic type. There are differences in the number of buds produced; and while in some genera buds may form from a relatively extensive region of the body wall, in others they are localized within a small area on each side. In some forms buds are produced slowly during the long period of growth of the parental individual as a functioning organism, in others either a single pair or a series are formed only during the developmental period of the parent. These variations can be regarded only as specializations in area and time, and do not affect the essential morphology of the process. Morphological differences are not great. They relate to the distance a palleal outgrowth extends before its tip starts to develop as a bud, whether separation of the tip from its stalk is necessary before development starts, and whether nutrition of the buds is effected by a secondary reattachment to a colonial vascular system or is met by accumulation of reserve material between the inner and outer vesicle of the bud. The bud proper always consists of an outer epidermal vesicle enclosing an inner vesicle 
derived from the atrial epithelium, the latter giving rise to all structures except epidermis.

It is simpler, and therefore more reasonable, to assume that this method of budding has been acquired on a single occasion by the group that exhibits it, than either that it has been acquired more than once or that all pleurogonid ascidians at one time possessed it, and the majority have lost it at different times.

The conclusion that all styelid and botryllid ascidians exhibiting palleal budding comprise a natural group is reinforced by a study of the tadpole larvae. Without exception, every species so far known that forms buds from the atrial body wall produces tadpoles with a 'photolith'. On the other hand, a photolith is not developed in the tadpole of any other ascidian species. All photoliths consist of a single-celled otolith developing from the floor of the sensory vesicle, the pigmented mass becoming hollowed out as a deep cup to receive the distal ends of a group of neurosensory cells growing out from the neural wall of the vesicle in the region where the ocellus occurs in other forms. The organ is responsive both to light and gravity. It is hardly conceivable that parallel evolution would so occur that two or more groups with palleal budding independently evolved a photolith. The coextension of the two features definitely indicates the existence of a single natural group.

At the same time, on the basis of adult structure, the relationship of Polycarpa and Polyandrocarpa is very close and hardly justifies anything greater than the generic distinction Van Name assigns them. This raises the question whether the Styelidae should be divided into two subfamilies, or whether the budding forms should be raised to full family status. This last may seem more logical, for the polystyelids as a whole exhibit great variability and as a group seem to have been launched on an independent evolutionary career of diversification, but it ignores the obvious relationship with the simple polycarpid styelids. There seems to be little justification for the maintenance of the botryllids, i.e. the genera Botryllus and Botrylloides, in a separate category, whether family, subfamily or any other, purely on the basis of the presence of zooid systems in the colonies. No such value is given to the presence or absence of systems in other families, e.g. Polyclinidae, and as Brien (1937) has shown they depend on buds being at equivalent developing stages and relatively close together. The striking end-result is out of proportion to the character leading to it. Accordingly the stand taken here is that there is a single natural group, the subfamily Botryllinae, characterized by palleal budding and the presence of a photolith in the tadpole larvae, combining with the Styelinae to form the Styelidae.

It is interesting within this group to try and determine the divergent paths of specialization. Species of Polyandrocarpa form a logical starting-point since there is reason to believe the genus is in every way, other than in budding and in the tadpole photolith, merely a slightly dwarfed edition of the styelinid 
genus Polycarpa. In species of both genera there are four well-developed folds of the branchial sac on each side as in styelids generally, and the gonads are hermaphrodite units developing on both sides in the atrial or mantle wall, with eggs and testis follicles numerous in each gland in Polycarpa species and the larger species of Polyandrocarpa. Polycarpa species do not bud, and the tadpoles of all species investigated merely have the unicellular otolith, the ocellus and light responsiveness being absent. Polyandrocarpa species produce palleal buds, but belatedly and slowly, so that colonies consist usually of a small number of relatively large zooids. Eggs and tadpoles are larger than those of Polycarpa species but smaller than in other polystyelids. In both the smaller Polycarpa species (e.g. P. gracilis) and larger Polyandrocarpa forms (P. zorritensis, tincta, gavei, etc.), the hermaphrodite glands, or polycarps, develop as a series in the mantle wall along each side of the endostyle.

From such a beginning, specializations have occurred more or less independently in three directions, with regard to branchial structure, number and nature of gonads, and time and place of budding.

Budding inevitably leads to a reduction in the size of the zooids, and the more efficient the budding process the smaller the zooids become, since growth is directed more toward zooid multiplication than individual size increase. Colonies with small zooids may therefore have arisen several times within the family, and the secondary simplifications of body structure correlated with size reduction do not necessarily indicate an exclusive close relationship among such forms. In these, the four well-formed branchial folds of Polyandrocarpa species are reduced to various degrees.

In the subgenus Eusynstyela of Polyandrocarpa, zooids do not exceed Io $\mathrm{mm}$. in length, and reduction is noticeable in the number of longitudinal bars constituting each of the four branchial folds. In Stolonica and Gynandrocarpa they are similarly reduced, but in addition the number of folds is reduced from four to three. In Distomus the three folds are reduced to three groups of longitudinal vessels corresponding to, but not actually forming, folds. Where zooids are even smaller, not more than $5 \mathrm{~mm}$. long, all trace of folds as such is gone, but they are represented by evenly spaced inner longitudinal branchial vessels, 8 in Polyzoa opuntia, 5-6 in Alloeocarpa bacca and Metandrocarpa dura, 4 in Kukenthalia borealis and Symplegma viride, and 3 in Polyzoa translucida, and the species of Botryllus, Botrylloides, and Chorizocarpa. Since there is such a correlation of branchial reduction with reduction in zooid size as a whole, branchial structure by itself cannot be used as a basis for relating species or genera.

With regard to the reproductive organs a somewhat similar situation exists. The first sign of a reduction effect in both Polycarpa and Polyandrocarpa species is a limitation of polycarps from a scattered arrangement to two rows parallel to the endostyle. With further reduction in the size of the zooids to the small dimensions of those in colonies of Symplegma, Botryllus, Botrylloides 
Kukenthalia and Chorizocarpa, a single polycarp is all that can be accommodated on each side of the body. In all of these forms there is further an increase in the size and reduction in number of ova produced by the ovarian component of the polycarp, when compared with a polycarp of species of Polyandrocarpa. These genera, accordingly, may form a natural subdivision, or again may merely show converging structure due to a comparable degree of body size reduction.

The gonads in Polyandrocarpa are undoubtedly the least modified within the group, with regard to the distribution, number, and nature of each. In Polyzoa conditions are similar, except that the units are smaller, both the number of ova and testis follicles being greatly reduced. Stolonica has changed little in number and distribution, but the acquisition of a relatively enormous egg size results in the ovary becoming functionally a virtual one-egg ovary, even though other oocytes may be present. The formation of anterior male and posterior hermaphrodite polycarps can be interpreted on the basis of an anteroposterior gradient in the size of the polycarp rudiments at the initiation of their development. In Metandrocarpa (s. Goodsiria) polycarps are of a single sex, and on both sides there are female gonads with large eggs in the anterior part and male gonads consisting of a single testis in the posterior part (Ritter, I896); while in Distomus (s. Alloeocarpa) ovaries with no trace of testis are found in the anterior part of the right side, and testes alone in the posterior part of the left side. Eggs are large and mature singly in both Metandrocarpa and Distomus.

A comparison of budding has to be less complete since too little is known in some cases, especially concerning the time and localization of the young buds. In general, however, the different genera comprise two groups, one in which budding is essentially a process performed by functional zooids during their later growth phase, and in which buds may grow out from various parts of the posterior and ventral atrial wall; and the other in which there is a small single bud-producing area in the latero-ventral wall.

The interrelations of the various genera therefore are complex and obscure. There has apparently been diverse evolution independently in the three features, branchial structure, nature of gonads, and time and place of budding. Much more detailed information is needed for all but Botryllus, Botrylloides, Symplegma (cf. Berrill, 1940), Stolonica and Distomus. At the same time Botryllus, Botrylloides, Symplegma, Kukenthalia and Chorizocormus do have in common the following characters: three inner longitudinal vessels in the branchial sac, a single polycarp on each side, with eggs of a comparable size, and on one side or both budding is confined to a very small area of the lateral wall immediately anterior to the gonad. This may be an instance of parallel evolution, but coincidence of the three features is considerable and it is difficult to avoid the conclusion that at least these five genera form a natural subdivision of the polystyelids. 


\section{REFERENCES}

ÄRNBÄCK-CHRISTIE-LINDE, A., I923. Northern and Arctic invertebrates in the collection of the Swedish State Museum. IX, Tunicata; 2, Botryllidae: reproductive organs of Metrocarpa (n.gen.) leachi Savigny and Botryllus schlosseri Pallas. Kungl. Sven. Vet. Handl., Bd. LxIII, pp. I-25.

Berrill, N. J., I940. The development of a colonial organism, Symplegma viride. Biol. Bull., Vol. Lxxix, pp. 272-8I.

BrIen, P., I937. Formation des Coenobies chez les Polyclinidae. Ann. Soc. Roy. Zool. Belg., T. LxvII, pp. 63-73.

ConkLIN, E. G., I905. The organization and cell-lineage of the ascidian egg. Fourn. Acad. Nat. Sci. Philadelphia, Vol. xIII, pp. I-II9.

- I93I. The development of centrifuged eggs of ascidians. Fourn. Exp. Zool., Vol. LX, pp. I-78.

GarstanG, S. L. \& Garstang, W., I928. On the development of Botrylloides, and its bearings on some morphological problems. Quart. Fourn. Micr. Sci., Vol. Lxxir, pp. I-49.

Grave, C., I921. Amaroucium Constellatum (Verrill). II. The structure and organization of the tadpole larva. Fourn. Morph., Vol. xxxvI, pp. 7I-IOI.

Grave, C. \& Woodbridge, H., 1924. Botryllus schlosseri. The behaviour and morphology of the free-swimming larva. Fourn. Morph., Vol. xxxIx, pp. 207-47.

LaCaZe-Duthiers, F. \& Delage, Y., I892. Études sur les Ascidies des côtes de France. Faune de Cynthiadées. Mém. Acad. Sci. France (2), T. xLv, pp. I-323.

Michaelsen, W., I904. Revision der composite Styeliden oder Polyzoinen. Mitt. Nat. Mus. Hamburg, Bd. Xxi, pp. I-I24.

OKA, A., I926. On a mode of gemmation in Dictyostela depressa n.g. n.sp. Proc. Imp. Acad. Fapan, Vol. II, pp. 348-5I.

RITTER, W. E., I896. Budding in compound ascidians, based on studies on Goodsiria and Perophora. Fourn. Morph., Vol. xiI, pp. I49-238.

Selys-Longchamps, M. DE, I9I7. Sur le bourgeonnement des Polystyélinés Stolonica et Heterocarpa avec quelques notes sur l'anatomie de ces deux genres. Bull. Sci. France Belg., T. L, pp. I70-276.

Van Name, W. G., 1945. The North and South American ascidians. Bull. Amer. Mus. Nat. Hist., Vol. Lxxxiv, pp. I-476. 